\title{
Effect of Die Configuration on the Physico-Chemical Properties, Anti-Nutritional Compounds, and Sensory Features of Legume-Based Extruded Snacks
}

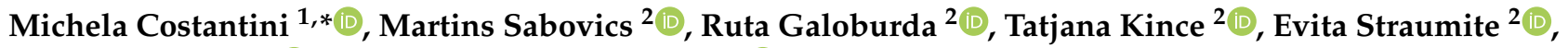 \\ Carmine Summo ${ }^{1}$ (D) and Antonella Pasqualone ${ }^{1, *(D)}$ \\ 1 Department of Soil, Plant and Food Science (DISSPA), University of Bari Aldo Moro, Via Amendola, 165/A, \\ I-70126 Bari, Italy; carmine.summo@uniba.it \\ 2 Department of Food Technology, Latvia University of Life Sciences and Technologies, Rigas Iela 22, \\ LV-3004 Jelgava, Latvia; martins.sabovics@llu.lv (M.S.); ruta.galoburda@llu.lv (R.G.); \\ tatjana.kince@llu.lv (T.K.); evita.straumite@llu.lv (E.S.) \\ * Correspondence: michela.costantini.92@gmail.com (M.C.); antonella.pasqualone@uniba.it (A.P.)
}

check for updates

Citation: Costantini, M.; Sabovics, M.; Galoburda, R.; Kince, T.; Straumite, E.; Summo, C.; Pasqualone A. Effect of Die Configuration on the Physico-Chemical Properties, Anti-Nutritional Compounds, and Sensory Features of Legume-Based Extruded Snacks. Foods 2021, 10, 3015. https://doi.org/10.3390/ foods10123015

Academic Editors: Raquel Olías, Alfonso Clemente and

Antonello Santini

Received: 4 November 2021

Accepted: 1 December 2021

Published: 5 December 2021

Publisher's Note: MDPI stays neutral with regard to jurisdictional claims in published maps and institutional affiliations.

Copyright: (c) 2021 by the authors. Licensee MDPI, Basel, Switzerland. This article is an open access article distributed under the terms and conditions of the Creative Commons Attribution (CC BY) license (https:// creativecommons.org/licenses/by/ $4.0 /)$.

\begin{abstract}
Legumes are not valued by all consumers, mostly due to the prolonged soaking and cooking process they require. This problem could be solved by preparing legume-based ready-to-eat snacks. In this study, the effect of two different dies (circular and star-shaped, with cross-sections of 19.6 and $35.9 \mathrm{~mm}^{2}$, respectively) on the physico-chemical properties, anti-nutritional compounds, and sensory features of extruded breakfast snacks was determined. Extruded products were obtained from $100 \%$ legume flours of red lentil, faba bean, brown pea, and common bean. The extrusioncooking conditions were $2.5 \mathrm{~g} / \mathrm{s}$ feed rate; $160 \pm 1{ }^{\circ} \mathrm{C}$ die temperature; $16 \pm 1 \mathrm{~g} / 100 \mathrm{~g}$ feed moisture, and $230 \mathrm{rpm}$ screw speed. Star-shaped extrudates showed a lower expansion ratio, degree of starch gelatinization, and water solubility index, as well as higher bulk density, hardness, crunchiness, and lightness $\left(L^{*}\right)$ values. The oligosaccharides showed non univocal variations by changing the die, whereas phytates did not vary at all. The extrudates from lentil flour (richer in fiber) were the least preferred by sensory panelists, due to their hard texture. However, the spherical extrudates were preferred over the star-shaped product. These results emphasize the possibility of improving the physico-chemical and sensory properties of legume extrudates by selecting a proper die.
\end{abstract}

Keywords: extrusion-cooking; legumes; extruder die; texture profile; phytates; oligosaccharides

\section{Introduction}

Appreciated by vegetarians, vegans, and suitable for coeliac patients, legumes play an important role in human health due to their nutritional composition [1]. Rich in proteins and complex carbohydrates, legumes are also characterized by their low-fat content [2]. Furthermore, they are an excellent source of dietary fiber, B-group vitamins and minerals [3]. However, legumes preparation is a time-consuming step, mainly due to the prolonged soaking and cooking process these grains require. This problem, which reduces their consumption by consumers, could be solved by developing new food products, such as legume-based ready-to-eat snacks [1].

Extrusion-cooking is a low cost, multifunctional and versatile food processing technique, which subjects raw materials to heat, pressure, and shear forces causing, among major biochemical effects, starch gelatinization, protein denaturation, fiber degradation, amylose-lipid complex formation, and Maillard reaction [4]. This technique is largely used for the development of ready-to-eat expanded snacks with different shapes, textures, and colors, characterized by enhanced flavor [5].

In recent years extensive research has been carried out to develop extruded products from legumes [6,7], in most cases blended with cereals [1,8-10]. Specific studies evaluated 
the effect of extrusion-cooking parameters, such as feed moisture, extrusion temperature, and screw speed on the nutritional [11], physico-chemical [8,10], textural [12,13], and sensory characteristics [14] of the final product, also by means of trials directly carried out at industrial level [15]. However, no studies were carried out on the effect of the die, which determined the shape and size of the finished products during the extrusion of the legumes.

Food shape and size are particularly important in capturing consumer attention [16]. These characteristics strongly influence the implicit associations that individuals make regarding an object and its value [17]. In addition, shape and size may significantly influence the physico-chemical characteristics [18] and even the sensory properties of food [19].

The aim of this study was, therefore, to determine the effect of two different die configurations (circular and star-shaped, with cross-sections of 19.6 and $35.9 \mathrm{~mm}^{2}$, respectively) on the physico-chemical properties, anti-nutritional compounds, and sensory features of extruded breakfast snacks prepared from $100 \%$ legume flour (red lentil, faba bean, brown pea, and common bean).

\section{Materials and Methods}

\subsection{Materials}

Dehulled legume flours from four different species, specifically red lentil (Lens culinaris Medik.), faba bean (Vicia faba L.), brown pea (Pisum sativum L.), and common bean (Phaseolus vulgaris L.) were used to obtain extruded snacks. Red lentil flour was purchased from a local market, the faba bean and brown pea flours were supplied by Ltd. Aloja-Starkelsen (Ungurpils, Latvia), and the common bean flour was supplied by the Priekuli Research Centre (Institute of Agricultural Resources and Economics, Priekuli district, Latvia). All flours were sieved on a $0.25 \mathrm{~mm}$ screen. The nutritional characteristics of these flours (as reported on the labels) are shown in Table 1.

Table 1. Proximate composition and energy value of red lentil, faba bean, brown pea and common bean flours. All values are expressed on fresh matter.

\begin{tabular}{lcccc}
\hline & Red Lentil & Faba Bean & Brown Pea & Common Bean \\
\hline Fats $(\mathrm{g} / 100 \mathrm{~g})$ & 1.10 & 1.39 & 1.97 & 1.51 \\
Carbohydrates $(\mathrm{g} / 100 \mathrm{~g})$ & 29.50 & 58.90 & 47.80 & 49.88 \\
Total dietary fibers $(\mathrm{g} / 100 \mathrm{~g})$ & 30.50 & 8.40 & 10.50 & 15.50 \\
Proteins $(\mathrm{g} / 100 \mathrm{~g})$ & 25.80 & 17.80 & 25.10 & 21.40 \\
Energy value $(\mathrm{kcal} / 100 \mathrm{~g})$ & 292.10 & 336.00 & 330.00 & 329.71 \\
\hline
\end{tabular}

\subsection{Flour Conditioning}

Flours were conditioned to reach the optimal moisture content for extrusion (16 g/ $100 \mathrm{~g}$ ), as determined in the preliminary experimental tests. Considering the moisture content of each flour type $(12.95 \pm 0.01,10.87 \pm 0.01,12.54 \pm 0.06$ and $11.46 \pm 0.06 \mathrm{~g} / 100 \mathrm{~g}$ for red lentil, faba bean, brown pea, and common bean flour, respectively), the amount of water to be added was calculated. Water was then progressively added to flour in a dough mixer (BEAR Varimixer AR10, Wodschow \& Co., Brondby, Denmark) at a medium speed, to avoid the formation of lumps, until an evenly hydrated flour was obtained (about $20 \mathrm{~min})$.

\subsection{Extrusion-Cooking Process}

The extrusion-cooking process was carried out using a DSE30 Lab Twin-screw extruder (Jinan Sunward Machinery Co., Ltd., Jinan City, China) with an extrusion capacity of $12 \mathrm{~kg} / \mathrm{h}$. The extruder, which had a 5-kW motor, was equipped with two $38 \mathrm{CrMoAl}$ screws ( $32 \mathrm{~mm}$ diameter, $660 \mathrm{~mm}$ length, $500 \mathrm{rpm}$ maximum screw speed). The operating conditions, selected in the preliminary experimental tests, were as follows: feed rate, $2.5 \mathrm{~g} / \mathrm{s}$; barrel temperature of the three heating zones $=55,95$, and $125^{\circ} \mathrm{C}$, respectively; die 
temperature, $160^{\circ} \mathrm{C}$; feed moisture, $16 \mathrm{~g} / 100 \mathrm{~g}$; screw speed, $230 \mathrm{rpm}$. Two different dies, with a circular and a star-shaped hole, were used (Figure 1). The cross-section of the circular die nozzle was $19.6 \mathrm{~mm}^{2}$, whereas the star cross-section area accounted for $35.9 \mathrm{~mm}^{2}$. Both die holes had a length of $6.35 \mathrm{~mm}$. To analyze the water absorption index, water solubility index, starch gelatinization degree, color, phytate and oligosaccharides content, the extrudates were ground by using an electric grinder HM-5735 (Hoomei Electrical Appliance Co., Monza, Italy), to pass through a $0.25 \mathrm{~mm}$ sieve. The other analyses were carried out on the entire extrudates.
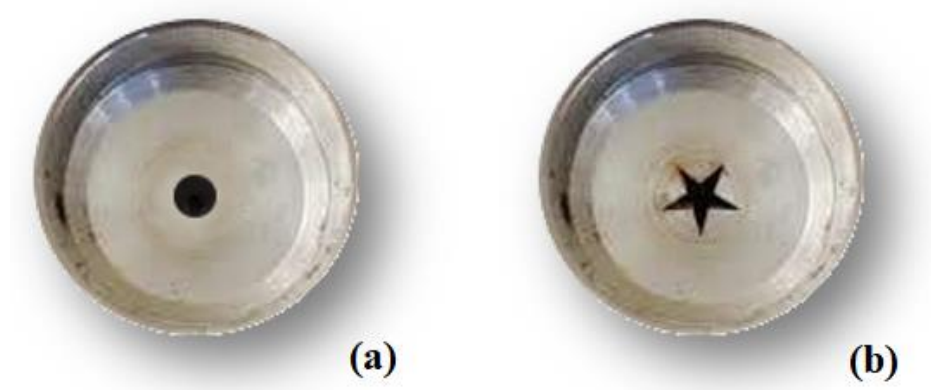

Figure 1. Circular (a) and star-shaped (b) dies used in the experimental trials.

\subsection{Bulk Density and Expansion Ratio}

Bulk density (BD) of the extruded products was determined by a rapeseed displacement method, and calculated according to the Equation (1) reported by Koksel and Masatcioglu [20]. Randomly selected whole pieces $(10 \pm 0.1 \mathrm{~g})$ of each type of extruded product were weighted:

$$
\mathrm{BD}\left(\mathrm{g} / \mathrm{cm}^{3}\right)=\mathrm{We} \times \mathrm{Ve}^{-1}=\mathrm{We} \times\left(\rho \mathrm{s} \times \mathrm{Ws}^{-1}\right)
$$

where, We and Ve are the weight $(\mathrm{g})$ and the equivalent volume $\left(\mathrm{cm}^{3}\right)$ of the extruded products, respectively. Ve coincides with the ratio between the rapeseed density ( $\rho$ ) and the rapeseed weight (Ws), with the same volume as the extrudates. Five replicates for each sample were carried out.

The expansion ratio (ER) was calculated as the ratio of extruded product diameter (measured using a calliper) to extruder die hole diameter, as reported by Koksel and Masatcioglu [20]. Ten replications were carried out.

\subsection{Water Absorption Index and Water Solubility Index}

The water absorption index (WAI) and the water solubility index (WSI) of the extruded products were determined according to Equations (2) and (3), reported by Janve and Singhal [21].

$$
\text { WAI }(\mathrm{g} / \mathrm{g})=(\text { weight of sediment }) /(\text { sample weight })
$$

WSI $(\mathrm{g} / 100 \mathrm{~g})=[($ weight of dry solids in supernatant $) /($ sample weight $)] \times 100$

The WSI is the weight of dry solids in the supernatant, whereas WAI is the weight of sediment without the supernatant per unit weight of the sample analyzed. The determination was carried out in triplicate.

\subsection{Degree of Starch Gelatinization (DG)}

The degree of starch gelatinization (DG) of the extruded products was determined using the method reported by Liu et al. [22], based on the formation of a blue iodine complex with amylose released during gelatinization, with slight modifications. Then, $40 \mathrm{mg}$ of sample was dissolved in $50 \mathrm{~mL}$ of $0.15 \mathrm{M} \mathrm{KOH}$, the suspension was mixed for $15 \mathrm{~min}$, and then centrifuged for $10 \mathrm{~min}$ at $4032 \times \mathrm{g}$ to remove the insoluble sediment. After centrifugation, $1 \mathrm{~mL}$ of supernatant was neutralized with $9 \mathrm{~mL}$ of $0.017 \mathrm{M} \mathrm{HCl}$. Subsequently, $0.1 \mathrm{~mL}$ of iodine reagent (prepared by dissolving $1 \mathrm{~g}$ iodine and $4 \mathrm{~g}$ potassium iodine in $100 \mathrm{~mL}$ of water) was added to the neutralized solution. After mixing, the 
absorbance was measured at $600 \mathrm{~nm}$ (A1) using a Cary 60 UV-VIS spectrophotometer (Agilent Technologies Inc., Santa Clara, CA, USA). For each sample, a control was prepared by using $1 \mathrm{M} \mathrm{KOH}$ and $0.1 \mathrm{M} \mathrm{HCl}$ instead of $\mathrm{KOH}(0.15 \mathrm{M})$ and $\mathrm{HCl}(0.017 \mathrm{M})$. The average of three measurements was taken and the DG was computed using the Equation (4):

$$
\mathrm{DG}=\mathrm{A} 1 / \mathrm{A} 2
$$

where A1 and A2 are the absorbance at $600 \mathrm{~nm}$ of sample and control, respectively.

\subsection{Texture Analysis}

Texture analysis was carried out using the TA.HD. Plus texture analyzer (Stable Microsystems Ltd., Godalming, UK) equipped with a cylindrical probe, with a diameter of $4.5 \mathrm{~cm}$ and a back extrusion cell with an inner diameter and height of 5.0 and $7.0 \mathrm{~cm}$ (Stable Microsystems Ltd.), respectively. The cell was filled with $100 \mathrm{~mL}$ of extruded products and the sample was compressed to $50 \%$ of the original height, as described by Smith and Hardacre [23]. The test was conducted at the following conditions: $1.0 \mathrm{~mm} / \mathrm{s}$ pre-test speed; $5.0 \mathrm{~mm} / \mathrm{s}$ test speed; $10 \mathrm{~mm} / \mathrm{s}$ post-test speed; $0.049 \mathrm{~N}$ trigger force; $1 \mathrm{kN}$ load cell. Hardness value was considered as the maximum compression force and expressed in Newtons (N). Crispiness was the number of positive peaks in the force versus time graph, while crunchiness (N.s) was the linear distance of the rugged lines obtained from the same graph. A greater number of positive peaks indicated a greater number of fracture events, thus, crisper extrudates. A longer linear distance resulted in a longer drop from the peak for each fracture event on average, and thus, resulted in crisper extrudates [24]. Data acquisition was performed using the "Exponent" software (Stable Microsystems Ltd.). Five replications for each sample were carried out.

\subsection{Bowl Life Analysis}

The bowl life analysis was carried out using the method reported by Oliveira et al. [25], with slight modifications. Briefly, $100 \mathrm{~mL}$ of extruded products were soaked in milk (fat content $2.5 \mathrm{~g} / 100 \mathrm{~g}$ ) at $5{ }^{\circ} \mathrm{C}$ for $3 \mathrm{~min}$, and then drained for $10 \mathrm{~s}$. Subsequently, texture analysis of the milk-soaked extruded products was performed under the same conditions as described above for the dry products. Five replications were carried out.

\subsection{Color Determination}

The color of the flours and the extruded products were determined using the CM-600d colorimeter (Konica Minolta Sensing Inc., Osaka, Japan) equipped with the SpectraMagic NX software (Konica Minolta, Tokyo, Japan). Lightness $\left(L^{*}\right)$, redness $\left(a^{*}\right)$, and yellowness $\left(b^{*}\right)$ were determined. Five replications were carried out.

\subsection{Determination of Total Phytates Content}

Total phytate content of flours and extruded products was determined according to the method reported by Summo et al. [26]. In order to express the phytate content in the sample, expressed as $\mathrm{mg} / \mathrm{g}$ of phytic acid on dry matter, the results were multiplied by 0.282 (molar ratio of phytate-phosphorus in a molecule of phytate). Three replications were carried out.

\subsection{Determination of Oligosaccharides}

Oligosaccharides (verbascose, stachyose and raffinose) of flours and extruded products were determined by high-performance liquid chromatography (HPLC) (Agilent Technologies, Santa Clara, CA, USA), equipped with a $300 \times 7.8 \mathrm{~mm}$ cation exchange column (Rezex RCM column, $\mathrm{Ca}^{2+}, 8 \mu \mathrm{m}$, Torrance, CA, USA) and Refractive Index Detector (RID 1260, Agilent Technologies), as previously reported in De Angelis et al. [27] with few modifications. Then, $10 \mathrm{mg}$ of flour or ground sample were dispersed in $10 \mathrm{~mL}$ of deionized water, stirred for $5 \mathrm{~min}$ and filtered through $0.22 \mu \mathrm{m}$ cellulose acetate filter. The HPLC separation was conducted isocratically at a flow rate of $0.8 \mathrm{~mL} / \mathrm{min}$, a column tempera- 
ture of $80{ }^{\circ} \mathrm{C}$ and a RID temperature of $40{ }^{\circ} \mathrm{C}$. Deionized water was used as the mobile phase. The identification was carried out by comparing the retention time with that of the corresponding standard (Merck KGaA, Darmstadt, Germany). A calibration curve for each oligosaccharide was prepared for the quantification. The analysis was carried out in triplicate and the results were expressed as $\mathrm{mg} / \mathrm{g}$ of each oligosaccharide on dry matter.

\subsection{Sensory Evaluation}

Twenty-eight semi-trained panelists from the Faculty of Food Technology, Latvia University of Life Sciences and Technologies (Jelgava, Latvia) evaluated the liking of legume-based extruded snacks according to a ranking test [28]. The samples, coded with random numbers and arranged in pieces of 3 on transparent glass plates, were randomly placed on the tray to be served to each panelist at the same time. For taste neutralization between samples, warm black tea was used. Panelists were asked to arrange the extruded product samples from 1 (the most-liked sample) to 8 (the least-liked sample), according to their degree of liking for four sensory attributes (appearance, texture, taste, and aftertaste), using the evaluation form generated by Fizz Acquisition 2.51 software (Biosystems, Couternon, France). The obtained data were reported as sum of ranks for each sample.

\subsection{Statistical Analysis}

The experimental data of the legume flours and the extruded products were subjected to one-way ANOVA and two-way ANOVA, respectively, followed by the Tukey's HSD test. The two-way ANOVA analysis was carried out considering the type of legume flour and the type of die as factors. Significant differences among the values of all parameters were determined at $p<0.05$ by the Minitab 17 Statistical Software (Minitab, Inc., State College, PA, USA, 2010). Data obtained from the sensory evaluation were statistically analyzed by the Friedman test using Fizz Calculation 2.60 software (Biosystems, Couternon, France), resulting in a significance level set at $p<0.05$.

\section{Results and Discussion}

\subsection{Characteristics of Flours Used in the Experiments}

The flours used to produce the extruded snacks are shown in Figure 2. Significant differences in the color parameters $\left(L^{*}, a^{*}\right.$ and $\left.b^{*}\right)$ were found among them (Table 2). Red lentil flour had the highest $a^{*}$ and $b^{*}$ values and the lowest $L^{*}$ value. Common bean flour was the lightest, followed by brown pea and faba bean flours. Brown pea flour showed the lowest $a^{*}$ and $b^{*}$ values, the latter without a significant difference with common bean flour.

Significant differences $(p<0.05)$ among flours were observed in the content of antinutritional compounds (Table 3). Legumes contain several anti-nutritional compounds, including phytic acid and non-digestible oligosaccharides [29,30]. Phytates chelate several important divalent cations, such as $\mathrm{Fe}, \mathrm{Zn}, \mathrm{Ca}$, and $\mathrm{Mg}$, reducing their availability for absorption and use in the small intestine [31]. Raffinose family oligosaccharides, such as raffinose, verbascose and stachyose, cause flatulence and discomfort in humans [32]. 


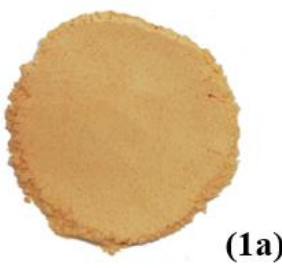

(1a)

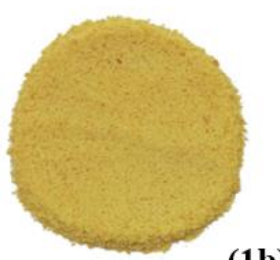

(1b)

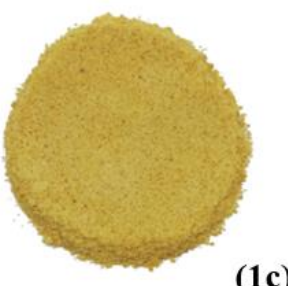

(1c)
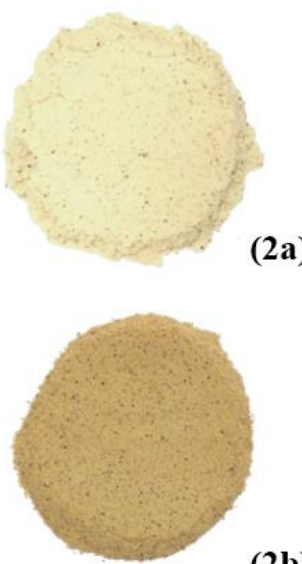

(2b)

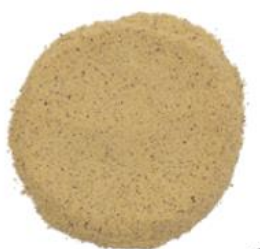

(2c)
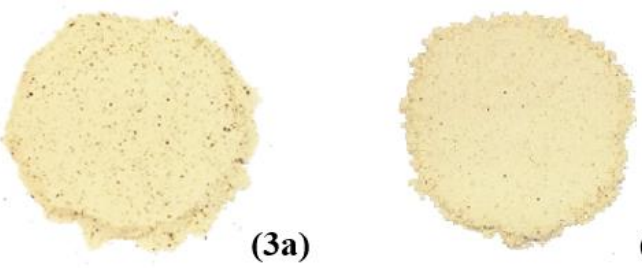

(4a)
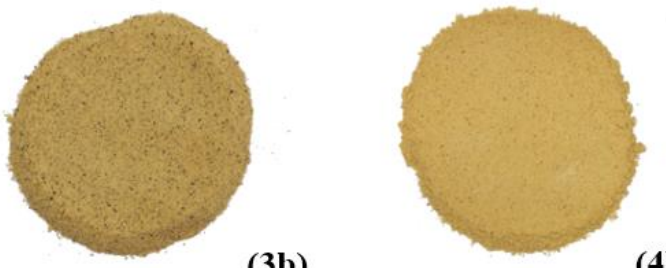

(3b)

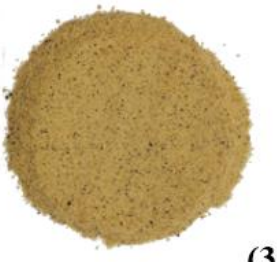

(3c)

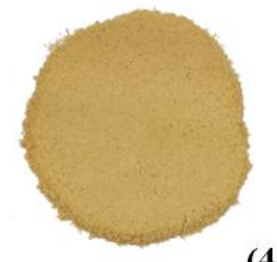

(4c)

Figure 2. Color of the legume-based extrudates. From left to right: flours and ground extrudates of red lentil (1), faba bean (2), brown pea (3), and common bean (4). The letter " $a$ " indicates the flours and the letters " $b$ " and " $c$ " indicate ground spherical and star-shaped extruded products, respectively.

Table 2. Color parameters (mean \pm standard deviation, $n=5$ ) of flours of red lentil, faba bean, brown pea, and common bean.

\begin{tabular}{ccccc}
\hline & Red Lentil & Faba Bean & Brown Pea & Common Bean \\
\hline$L^{*}$ & $84.79 \pm 0.36^{\mathrm{c}}$ & $87.56 \pm 0.03^{\mathrm{b}}$ & $87.85 \pm 0.31^{\mathrm{b}}$ & $89.12 \pm 0.37^{\mathrm{a}}$ \\
$a^{*}$ & $9.45 \pm 0.12^{\mathrm{a}}$ & $-0.49 \pm 0.03^{\mathrm{b}}$ & $-0.75 \pm 0.03^{\mathrm{c}}$ & $-0.56 \pm 0.02^{\mathrm{b}}$ \\
$b^{*}$ & $21.85 \pm 0.25^{\mathrm{a}}$ & $14.50 \pm 0.05^{\mathrm{b}}$ & $13.16 \pm 0.02^{\mathrm{c}}$ & $12.93 \pm 0.04^{\mathrm{c}}$ \\
\hline
\end{tabular}

Different letters in the rows indicate significant differences $(p<0.05)$ among legume flour.

Table 3. Anti-nutritional compounds (mean \pm standard deviation, $n=3$ ) of flours of red lentil, faba bean, brown pea, and common bean.

\begin{tabular}{lcccc}
\hline & Red Lentil & Faba Bean & Brown Pea & Common Bean \\
\hline Phytates (mg phytic acid/g d.m.) & $3.49 \pm 0.09^{\mathrm{d}}$ & $7.51 \pm 0.09^{\mathrm{b}}$ & $4.69^{\mathrm{a}} \pm 0.02^{\mathrm{c}}$ & $9.09 \pm 0.11^{\mathrm{a}}$ \\
Verbascose (mg/g d.m.) & $16.09 \pm 0.09^{\mathrm{b}}$ & $12.74 \pm 0.10^{\mathrm{c}}$ & $29.66 \pm 0.23^{\mathrm{a}}$ & $12.65 \pm 0.40^{\mathrm{c}}$ \\
Stachyose (mg/g d.m.) & $28.89 \pm 0.67^{\mathrm{c}}$ & $39.32 \pm 1.11^{\mathrm{a}}$ & $19.16 \pm 0.85^{\mathrm{d}}$ & $35.37 \pm 0.98^{\mathrm{b}}$ \\
Raffinose (mg/g d.m.) & $16.28 \pm 0.68^{\mathrm{a}}$ & $2.80 \pm 0.14^{\mathrm{d}}$ & $10.10 \pm 0.88^{\mathrm{b}}$ & $5.99 \pm 0.43^{\mathrm{c}}$ \\
\hline
\end{tabular}

Different letters in the rows indicate significant differences $(p<0.05)$ among legume flour.

Common bean flour had the highest content of phytates, followed by faba bean, brown pea, and red lentil flours, respectively, in agreement with other studies [33]. Brown pea flour was characterized by the highest verbascose, although it had the lowest stachyose content. Faba bean flour had the highest content of stachyose and the lowest content of raffinose. The content of oligosaccharides may vary among different legume species and varieties and depends on the growing environment [34]. Vidal-Valverde et al. [35] reported a high variability among 18 different varieties of pea for raffinose $(4.10-10.30 \mathrm{mg} / \mathrm{g})$, stachyose (10.70-26.7 mg/g) and verbascose $(0.00-26.70 \mathrm{mg} / \mathrm{g})$. Tahir et al. [36] found higher values of stachyose than raffinose and verbascose in 11 lentil varieties, in agreement with our 
findings. Oligosaccharides represent a major limitation for the extensive use of legumes, both at a domestic and an industrial level [37].

\subsection{Physico-Chemical Properties of Extruded Products}

Significant differences $(p<0.05)$ were found among the extruded products for all physico-chemical parameters, except for water absorption index (WAI), as a function of the legume used, the type of die, and their interaction (legume $\times$ die) (Table 4). WAI was not influenced by the type of die.

Table 4. Physico-chemical parameters (mean \pm standard deviation) of spherical and star-shaped extruded products obtained from different legume flours ( $n=5$ for BD; $n=10$ for ER; $n=3$ for the other parameters).

\begin{tabular}{|c|c|c|c|c|c|c|}
\hline \multirow{2}{*}{$\begin{array}{c}\text { Die } \\
\text { Configuration }\end{array}$} & \multirow[b]{2}{*}{ Legume } & \multicolumn{5}{|c|}{ Physico-Chemical Parameter } \\
\hline & & $\begin{array}{c}\text { BD } \\
\left(\mathrm{g} / \mathrm{cm}^{3}\right)\end{array}$ & ER & $\begin{array}{l}\text { WAI } \\
(g / g)\end{array}$ & $\begin{array}{c}\text { WSI } \\
(\mathrm{g} / 100 \mathrm{~g})\end{array}$ & $\begin{array}{c}\text { DG } \\
(\mathrm{g} / 100 \mathrm{~g})\end{array}$ \\
\hline \multirow{4}{*}{ Spherical } & Red lentil & $0.41 \pm 0.01^{b}$ & $2.10 \pm 0.22^{c}$ & $3.83 \pm 0.18^{a}$ & $9.32 \pm 0.30^{d}$ & $95.21 \pm 0.63^{c}$ \\
\hline & Faba bean & $0.21 \pm 0.02^{d}$ & $2.46 \pm 0.09^{b}$ & $3.22 \pm 0.05^{b}$ & $16.79 \pm 0.25^{\mathrm{a}}$ & $98.29 \pm 0.20^{\mathrm{a}}$ \\
\hline & Brown pea & $0.21 \pm 0.00^{d}$ & $2.78 \pm 0.12^{\mathrm{a}}$ & $3.34 \pm 0.14^{b}$ & $12.99 \pm 0.89^{b}$ & $96.96 \pm 0.66^{b}$ \\
\hline & Common bean & $0.20 \pm 0.01^{\mathrm{d}}$ & $2.56 \pm 0.23^{b}$ & $2.49 \pm 0.09^{c}$ & $12.95 \pm 0.61^{b}$ & $98.05 \pm 0.05^{\mathrm{a}}$ \\
\hline \multirow{4}{*}{ Star-shaped } & Red lentil & $0.60 \pm 0.03^{a}$ & $1.14 \pm 0.04^{\mathrm{f}}$ & $4.05 \pm 0.20^{\mathrm{a}}$ & $7.68 \pm 0.36^{\mathrm{e}}$ & $96.82 \pm 0.21^{b}$ \\
\hline & Faba bean & $0.27 \pm 0.02^{c}$ & $1.56 \pm 0.05^{\mathrm{de}}$ & $2.60 \pm 0.03^{c}$ & $13.08 \pm 0.56^{\mathrm{b}}$ & $93.25 \pm 0.14^{\mathrm{d}}$ \\
\hline & Brown pea & $0.27 \pm 0.01^{c}$ & $1.70 \pm 0.17^{\mathrm{d}}$ & $3.33 \pm 0.02^{b}$ & $10.62 \pm 0.20^{\mathrm{cd}}$ & $92.75 \pm 0.40^{d}$ \\
\hline & Common bean & $0.25 \pm 0.01^{\mathrm{c}}$ & $1.42 \pm 0.07^{\mathrm{e}}$ & $2.81 \pm 0.18^{c}$ & $11.77 \pm 0.61 \mathrm{bc}$ & $96.99 \pm 0.01^{b}$ \\
\hline Legume & & $p<0.001$ & $p<0.001$ & $p<0.001$ & $p<0.001$ & $p<0.001$ \\
\hline Die & & $p<0.001$ & $p<0.001$ & $p=0.659$ & $p<0.001$ & $p<0.001$ \\
\hline Legume $\times$ die & & $p<0.001$ & $p<0.05$ & $p<0.001$ & $p<0.01$ & $p<0.001$ \\
\hline
\end{tabular}

$\mathrm{BD}$ = bulk density; $\mathrm{ER}$ = expansion ratio; $\mathrm{WAI}=$ water absorption index; WSI = water solubility index; $\mathrm{DG}=$ degree of starch gelatinization. Different letters in column indicate significant differences $(p<0.05)$ between both shapes of products (sphere and star) considering the interaction between the two factors (legume and die).

Considering the legume type, the extruded products obtained from red lentil had the highest bulk density (BD) and WAI, as well as the lowest expansion ratio (ER) and water solubility index (WSI). Brown pea, instead, showed the highest ER. The spherical extrudates of brown pea, in particular, were well expanded and larger than others with the same shape (Figure 3). Common bean extrudates, both spherical and star-shaped, showed the highest degree of starch gelatinization (DG). All flours tended to expand more through the circular die, leading to extruded products characterized by higher ER, DG, and WSI, as well as a lower $\mathrm{BD}$, than the star-shaped ones.

The effect of the die could be explained by considering the different friction to which the product was subjected during the extrusion. The circular cross-section was smaller than the star-shaped one (19.6 vs. $35.9 \mathrm{~mm}^{2}$ ). Consequently, the conditioned flour was subjected to elevated levels of friction and pressure flowing through the circular die, compared with the star-shaped one. In turn, higher levels of friction induced heat generation and increased the actual extrusion temperature. Higher pressure and temperature are known to promote more expanded and less dense products [11,38], explaining the higher ER and lower BD of spherical extrudates. In addition, a specific effect of geometry can be hypothesized, not related to the size of the die hole. The star-shaped cross section is characterized by the presence of angles, absent in the circular one, which could have caused a mechanical breaking of bubbles in the gelatinized starchy matrix flowing through the die, further disturbing the expansion of the extrudate. The increase in the die nozzle diameter was found to cause a decrease in radial expansion in yellow corn extrudates [39]. A higher extrusion pressure also induces a higher degree of starch gelatinization [39], as was observed in the spherical extrudates, compared with the star-shaped ones, except for the red lentil-based products, due to their high fiber content. The presence of the fiber, in fact, restricted the starch gelatinization required for the expansion of the expanded 
snacks [40]. Starch gelatinization, in turn, positively influenced the volume expansion of the extrudate.
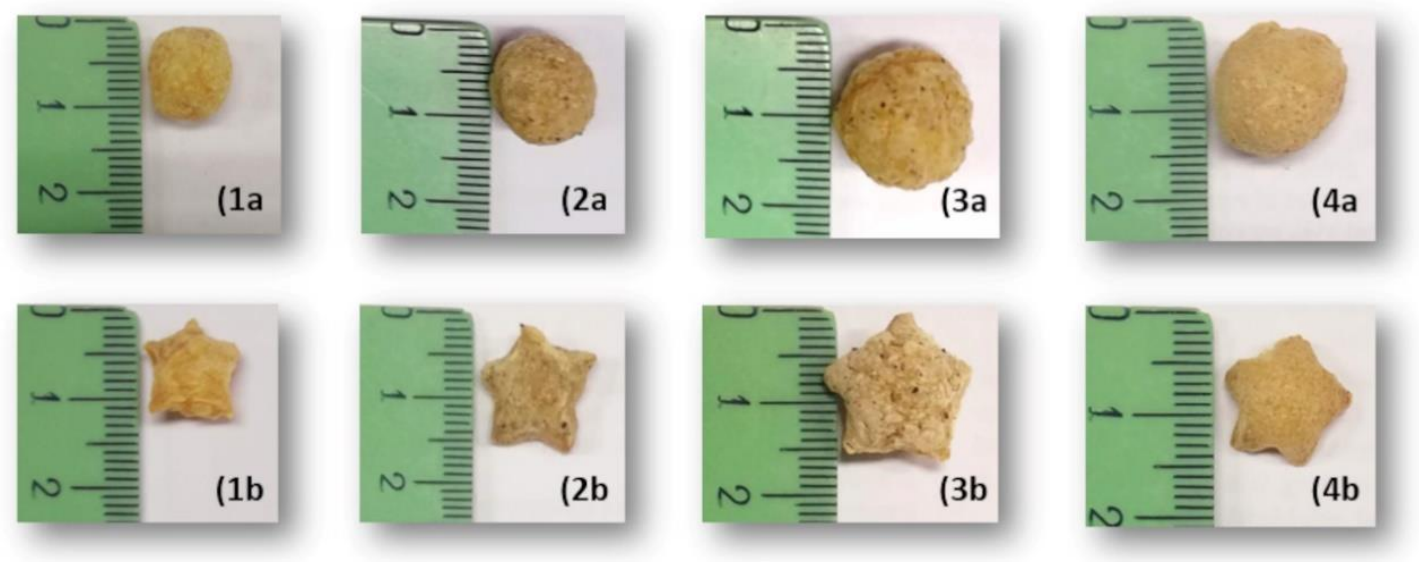

Figure 3. Size of the legume-based extrudates. From left to right: extrudates of red lentil (1), faba bean (2), brown pea (3) and common bean (4). The letters " $a$ " and " $b$ " indicate spherical and star-shaped extruded products, respectively.

ER and BD are physical parameters capable of influencing the consumer acceptability of extruded products [11]. Several studies reported an inverse relation between BD and ER $[8,11]$. The same trend was observed in our work, where a negative correlation between $\mathrm{BD}$ and ER $(r=-0.631 ; p=0.093)$ was found. Furthermore, the fiber present in the starting flour may also affect both of these parameters, as reported by other researchers [41-43]. Dietary fibers lead to cell-wall rupture, before air bubbles can expand, reducing the overall expansion [42]. As a result, extruded products with a high fiber content are usually compact and hard, not crispy, and have an undesirable texture [44]. Therefore, red lentil flour, showing the highest fiber content (Table 1), led to extrudates with the lowest ER and highest $\mathrm{BD}$.

The extrusion-cooking conditions related to the die used, as the presence of fibers could also influence the WAI and WSI values, representing the amount of water absorbable by the extruded product, and the quantity of soluble substances formed during the extrusion process from starch, proteins, and fibers [21].

WSI was influenced by all factors considered (legume, die and legume $\times$ die); however, the effect of die on WAI was found not significant. Regarding the effect of the type of legume on WAI, higher fiber levels, absorbing and retaining the water within a welldeveloped starch-protein-polysaccharide network, resulted in an increase in this parameter, as reported by Tas and Shah [45]. Furthermore, extrusion-cooking may induce structural modifications, such as the reduction in the fiber particle size increasing the surface area and, therefore, their water absorption capacity [46]. Although extrusion-cooking is known to induce an increase in the WSI parameter, due to the degradation of polymers to low molecular weight soluble compounds [47], other factors, such as the interaction between fiber and starch, might have affected WSI [48]. In fact, red lentil products, which had the highest total dietary fiber content, were characterized by the lowest WSI. WSI, which was influenced by the die configuration, was higher in spherical than in star-shaped extrudates, due to the increase in extrusion temperature induced by friction, in the case of the circular die.

\subsection{Texture of Dry and Milk-Soaked Extruded Products}

The texture analysis (Table 5) was not applicable to the red lentil extrudates, due to their particularly hard texture (confirmed by their high BD and low ER), exceeding the instrumental range of measure of the texture analyzer used. Other authors observed that extrudates with high $\mathrm{BD}$ and low ER were characterized by very large [21] to non-analyzable hardness [49]. A significant effect $(p<0.05)$ of the type of legume, die configuration and their 
interaction (legume $\times$ die) was observed for all textural parameters, except for crispness of dry products, which was not influenced by the die. Star-shaped extrudates were characterized by higher hardness and crunchiness than the spherical extrudates, in agreement with the ER and BD values. As for crispness, brown pea spherical extrudates were the crispiest, without significant differences to the brown pea star-shaped extrudates. This trend was due to the higher ER and lower BD and hardness values, which characterized both brown pea products. Koksel and Masatcioglu [20] reported a significant negative correlation between ER and hardness, as well as between BD and crispness, in yellow pea puffs. Other researchers reported that extrudates which were less hard and crunchy had higher crispness values $[25,50]$. Crispness and crunchiness are important quality attributes, used to describe the texture of extruded snack products. Consumer acceptability is strongly influenced by both crispness [51] and crunchiness [50,52]. Crispness and crunchiness are two sensations that in the human brain are induced by different stimuli, during the dynamic process of mastication [53]. Crispness could be identified as the perceived force necessary to separate the product into two or more distinct pieces during a single bite with the incisors [53]. Crisp products are characterized by a brittle and low-density structure, which easily breaks and generates loud and high-pitched sounds when fractured [54]. Crunchiness is the perceived intensity of repeated incremental failures of the product during a single complete bite with molar [53] teeth. Crunchy foods exhibit harder textures and emit sounds at lower frequencies than crisp foods [54].

Table 5. Texture (mean \pm standard deviation; $n=5$ ) of dry and milk-soaked spherical and star-shaped extruded products obtained from different legume flours.

\begin{tabular}{|c|c|c|c|c|c|c|c|}
\hline \multirow{2}{*}{$\begin{array}{c}\text { Die } \\
\text { Configuration }\end{array}$} & \multirow[b]{2}{*}{ Legume } & \multicolumn{3}{|c|}{ Dry } & \multicolumn{3}{|c|}{ Milk-Soaked (Bowl Life) } \\
\hline & & $\begin{array}{l}\text { Hardness } \\
\text { (N) }\end{array}$ & $\begin{array}{l}\text { Crunchiness } \\
\text { (N.s N.s) }\end{array}$ & Crispness & $\begin{array}{l}\text { Hardness } \\
\text { (N) }\end{array}$ & $\begin{array}{c}\text { Crunchiness } \\
\text { (N.s) }\end{array}$ & Crispness \\
\hline \multirow{4}{*}{ Spherical } & Red lentil & n.d. & n.d. & n.d. & n.d. & n.d. & n.d. \\
\hline & Faba bean & $606 \pm 7^{c}$ & $1799 \pm 84^{c}$ & $51.3 \pm 2.1^{\mathrm{cd}}$ & $395 \pm 3^{\mathrm{a}}$ & $610 \pm 10^{a}$ & $14.3 \pm 2.9^{b}$ \\
\hline & Brown pea & $477 \pm 13^{\mathrm{d}}$ & $2354 \pm 105^{b}$ & $71.0 \pm 3.6^{\mathrm{a}}$ & $384 \pm 16^{\mathrm{ab}}$ & $665 \pm 75^{a}$ & $27.0 \pm 1.7^{\mathrm{a}}$ \\
\hline & Common bean & $604 \pm 39^{c}$ & $1469 \pm 68^{\mathrm{d}}$ & $53.3 \pm 5.5^{\mathrm{cd}}$ & $303 \pm 1^{d}$ & $350 \pm 3^{c}$ & $8.0 \pm 1.0^{c}$ \\
\hline \multirow{4}{*}{ Star-shaped } & Red lentil & n.d. & n.d. & n.d. & n.d. & n.d. & n.d. \\
\hline & Faba bean & $747 \pm 21^{b}$ & $2582 \pm 87^{a b}$ & $59.7 \pm 2.5^{b c}$ & $355 \pm 6^{c}$ & $513 \pm 22^{b}$ & $15.0 \pm 2.0^{b}$ \\
\hline & Brown pea & $688 \pm 13^{b}$ & $2629 \pm 80^{a}$ & $65.7 \pm 2.3^{\mathrm{ab}}$ & $366 \pm 9 b c$ & $497 \pm 4^{b}$ & $19.0 \pm 1.0^{b}$ \\
\hline & Common bean & $1030 \pm 41^{\mathrm{a}}$ & $2372 \pm 129^{a b}$ & $50.0 \pm 1.0^{\mathrm{d}}$ & $393 \pm 8^{a}$ & $429 \pm 20$ bc & $9.3 \pm 1.2^{\mathrm{c}}$ \\
\hline Legume & & $p<0.001$ & $p<0.001$ & $p<0.001$ & $p<0.001$ & $p<0.001$ & $p<0.001$ \\
\hline Die & & $p<0.001$ & $p<0.001$ & $p=0.942$ & $p<0.05$ & $p<0.05$ & $p<0.05$ \\
\hline Legume $\times$ die & & $p<0.001$ & $p<0.001$ & $p<0.01$ & $p<0.001$ & $p<0.001$ & $p=0.001$ \\
\hline
\end{tabular}

n.d. $=$ not detectable. Different letters in the columns indicate the significant differences $(p<0.05)$ between both shapes of products (sphere and star) considering the interaction between the two factors (legume and die).

The obtained results may be explained again considering the effect of die size. A larger die cross section may reduce the viscosity and the capacity of mechanical energy dissipation inside the extruder, producing harder and less crispy products [25]. To assess the textural quality in the real conditions of consumption, the bowl life test was performed, by soaking the extrudates in milk. Usually, expanded products have a greater number of pores, which reduces the resistance to mass transfer and increases the rate of water absorption [55]. Milk, however, contains some fat, which may block the pores of the extrudates, reducing the absorption rate [55]. All the textural parameters decreased after soaking, due to milk absorption and consequent softening. Liquid uptake, indeed, modifies the microstructure and the mechanical strength of the extruded products by plasticizing and softening the starch and protein matrix [51]. Soaking caused a hardness reduction of 20, 35 and $50 \%$ for brown pea, faba bean, and common bean spherical extrudates, respectively. The star-shaped products behaved similarly, with a reduction of hardness ranging from 47 to $62 \%$ for brown pea and common bean extrudates, respectively. Crunchiness and 
crispness decreased even further, by $76 \%$ and $74 \%$ on average. The values of crispness agreed with those of other studies [56].

\subsection{Color of Extruded Products}

Color is one of the most important characteristics of a food product, due to its marked influence on consumer acceptability [20]. Color features are known to be influenced by the extrusion-cooking [7]. All extrudates were darker than the corresponding flours (Figure 2). Their overall appearance is shown in Figure 4. All color components were significantly influenced by legume type, die configuration and legume $\times$ die interaction (Table 6). Color features of the examined products were the result of existing pigments and the partial incidence of Maillard reaction, due to the extrusion-cooking conditions.
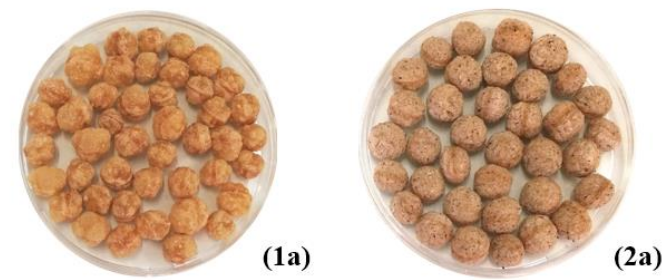

(2a)

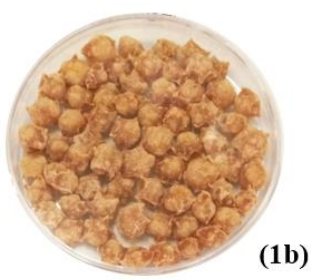

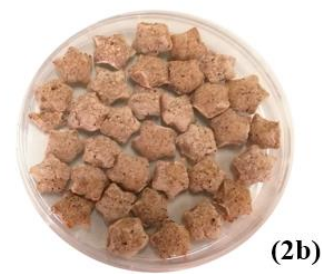
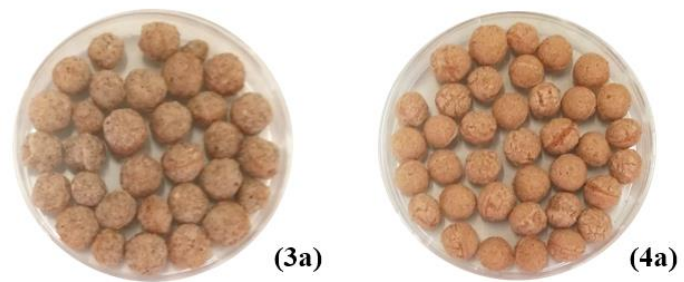

(4a)
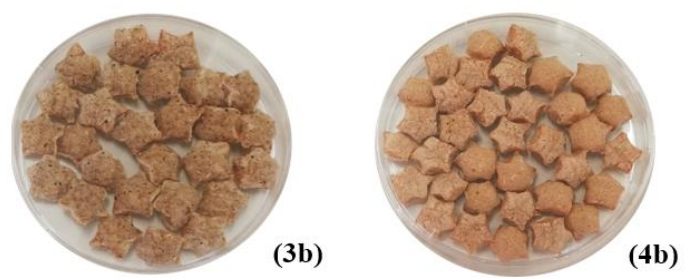

Figure 4. Overall appearance of the legume-based extrudates. From left to right: extrudates of red lentil (1), faba bean (2), brown pea (3) and common bean (4). The letters "a" and " $\mathrm{b}$ " indicate the spherical and star-shaped extruded products, respectively.

Table 6. Color parameters (mean \pm standard deviation; $n=5$ ) of spherical and star-shaped extruded products obtained from different legume flours.

\begin{tabular}{|c|c|c|c|c|}
\hline \multirow{2}{*}{$\begin{array}{c}\text { Die } \\
\text { Configuration }\end{array}$} & \multirow{2}{*}{ Legume } & \multicolumn{3}{|c|}{ Color Parameters } \\
\hline & & $L^{*}$ & $a^{*}$ & $b^{*}$ \\
\hline \multirow{4}{*}{ Spherical } & Red lentil & $74.64 \pm 0.07^{b}$ & $4.18 \pm 0.03^{c}$ & $31.88 \pm 0.02^{b}$ \\
\hline & Faba bean & $70.45 \pm 0.21^{\mathrm{f}}$ & $2.75 \pm 0.06^{\mathrm{e}}$ & $20.94 \pm 0.07^{\mathrm{f}}$ \\
\hline & Brown pea & $70.46 \pm 0.09^{f}$ & $2.55 \pm 0.05^{\mathrm{f}}$ & $19.54 \pm 0.03^{h}$ \\
\hline & Common bean & $72.64 \pm 0.04^{\mathrm{d}}$ & $4.91 \pm 0.01^{\mathrm{a}}$ & $24.54 \pm 0.05^{\mathrm{c}}$ \\
\hline \multirow{4}{*}{ Star-shaped } & Red lentil & $74.87 \pm 0.06^{\mathrm{a}}$ & $4.52 \pm 0.03^{b}$ & $33.24 \pm 0.04^{a}$ \\
\hline & Faba bean & $72.24 \pm 0.06^{\mathrm{e}}$ & $2.22 \pm 0.02^{h}$ & $20.70 \pm 0.08^{g}$ \\
\hline & Brown pea & $73.25 \pm 0.09^{c}$ & $2.39 \pm 0.02 \mathrm{~g}$ & $21.09 \pm 0.07^{\mathrm{e}}$ \\
\hline & Common bean & $75.04 \pm 0.02^{\mathrm{a}}$ & $4.09 \pm 0.01^{\mathrm{d}}$ & $24.12 \pm 0.02^{\mathrm{d}}$ \\
\hline Legume & & $p<0.001$ & $p<0.001$ & $p<0.001$ \\
\hline Die & & $p<0.001$ & $p<0.001$ & $p<0.001$ \\
\hline Legume $\times$ die & & $p<0.001$ & $p<0.001$ & $p<0.001$ \\
\hline
\end{tabular}

Different letters in the columns indicate significant differences $(p<0.05)$ between both shapes of products (sphere and star) considering the interaction between the two factors (legume and die).

All star-shaped products were characterized by higher $L^{*}$ and lower $a^{*}$ values (the latter with the exception of red lentil) than spherical ones. The $b^{*}$ index showed a nonunivocal trend. The temperature rises and shear stress related to the rotation of the screw during the extrusion can degrade pigments, especially carotenoids, with consequent color alterations [57]. The increase of $a^{*}$ and the decrease of $L^{*}$ may be also associated with 
the formation of brown polymers, namely melanoidins, during the Maillard reaction [12]. An increase of $b^{*}$ could be due to the formation, during the initial stages of the Maillard reaction, of yellow-colored compounds, or due to the thermal oxidation of lipids in the sample [12]. A die with a larger cross section results in lower pressure, and lower heat development during extrusion [38,58], leading to a less intense Maillard reaction. The consequences are a less pronounced browning and a reduced flavor development [11]. Therefore, the star-shaped extrudates, obtained through a larger cross-section which made the extrusion process less drastic, were lighter than the spherical ones.

\subsection{Anti-Nutritional Compounds of Flour and Extruded Products}

The extrusion-cooking processing conditions, and the type of raw material adopted, can both affect the amount of anti-nutritional compounds found in legume extrudates [7,59]. Comparing the native flours (Table 3) with the extrudates (Table 7), a different behavior was found for different anti-nutritional compounds. For both star-shaped and spherical products, phytates decreased during the extrusion-cooking of the faba bean $(12 \%$ on average), common bean ( $23.5 \%$ on average), and brown pea ( $7.9 \%$ on average) flours, probably due to the thermal treatment related to the extrusion-cooking process.

Table 7. Anti-nutritional compounds (mean \pm standard deviation; $n=3$ ) of spherical and star-shaped extruded products obtained from different legume flours.

\begin{tabular}{|c|c|c|c|c|c|}
\hline \multirow{2}{*}{ Die Configuration } & \multirow{2}{*}{ Legume } & \multirow{2}{*}{$\begin{array}{c}\text { Phytates Content } \\
\text { (mg Phytic Acid/g d.m.) }\end{array}$} & \multicolumn{3}{|c|}{ Oligosaccharide Content (mg/g d.m.) } \\
\hline & & & Verbascose & Stachyose & Raffinose \\
\hline \multirow{4}{*}{ Spherical } & Red lentil & $3.55 \pm 0.05^{d}$ & $17.02 \pm 0.27^{b}$ & $31.09 \pm 0.15^{\mathrm{d}}$ & $14.18 \pm 0.14^{b}$ \\
\hline & Faba bean & $6.53 \pm 0.21^{b}$ & $13.69 \pm 0.06^{c}$ & $41.45 \pm 0.64^{\mathrm{a}}$ & $3.84 \pm 0.02^{f}$ \\
\hline & Brown pea & $4.47 \pm 0.04^{c}$ & $28.48 \pm 0.48^{a}$ & $22.04 \pm 0.38^{\mathrm{e}}$ & $11.43 \pm 0.30^{c}$ \\
\hline & Common bean & $6.89 \pm 0.09^{a}$ & $12.51 \pm 0.42^{\mathrm{d}}$ & $34.76 \pm 0.42^{c}$ & $5.54 \pm 0.40^{\mathrm{e}}$ \\
\hline \multirow{4}{*}{ Star-shaped } & Red lentil & $3.55 \pm 0.11^{d}$ & $14.50 \pm 0.44^{\mathrm{c}}$ & $30.58 \pm 0.67^{\mathrm{d}}$ & $17.43 \pm 0.10^{a}$ \\
\hline & Faba bean & $6.66 \pm 0.22^{a b}$ & $14.08 \pm 0.62^{c}$ & $42.52 \pm 0.07^{\mathrm{a}}$ & $3.67 \pm 0.32^{f}$ \\
\hline & Brown pea & $4.17 \pm 0.03^{c}$ & $28.70 \pm 0.12^{\mathrm{a}}$ & $22.45 \pm 0.38^{\mathrm{e}}$ & $11.08 \pm 0.04^{c}$ \\
\hline & Common bean & $6.98 \pm 0.03^{a}$ & $11.41 \pm 0.41^{\mathrm{d}}$ & $37.31 \pm 1.04^{b}$ & $6.93 \pm 0.36^{d}$ \\
\hline Legume & & $p<0.001$ & $p<0.001$ & $p<0.001$ & $p<0.001$ \\
\hline Die & & $p=0.655$ & $p<0.001$ & $p=0.001$ & $p<0.001$ \\
\hline Legume $\times$ die & & $p<0.05$ & $p<0.001$ & $p<0.01$ & $p<0.001$ \\
\hline
\end{tabular}

Different letters in the columns indicate significant differences $(p<0.05)$ between both shapes of products (sphere and star) considering the interaction between the two factors (legume and die).

Ciudad-Mulero et al. [60] reported a greater reduction of total phytates in lentil flour extruded at 160 than at $140{ }^{\circ} \mathrm{C}$. Oligosaccharides, on the contrary, increased, especially stachyose, and raffinose. This result could be due to the high temperature and pressure adopted during the extrusion-cooking process, which can break the bonds between oligosaccharides and other macromolecules, or may change the structure of the food matrix, improving the extractability of these compounds [59]. The same findings were reported by other researchers in extruded lentil snacks and in pea-rice gluten free expanded products $[59,61]$.

Significant differences $(p<0.05)$ were found for verbascose, stachyose and raffinose as a function of the type of legume, die configuration, and their interaction (legume $\times$ die), whereas phytic acid was not influenced by the die. Red lentil spherical extrudates were characterized by significantly higher verbascose content than star-shaped ones, whereas raffinose increased by approximately $7 \%$ in the latter. Common bean stars had higher stachyose and raffinose content than spheres obtained from the same flour. In particular, considering the spherical products, a reduction of both stachyose and raffinose by 1.7 and $7.5 \%$ was found, respectively. No significant differences were found between the two die shapes in the faba bean and brown pea extrudates, for all the oligosaccharides. Therefore, the behavior of single oligosaccharides depended on the extrusion conditions employed 
which, in turn, were related to the size and shape of the die cross-section, but also greatly depended on the type of legume considered. A higher extrusion temperature and pressure may induce the hydrolysis of verbascose into raffinose and stachyose, increasing their contents [61], as found in the brown pea extrudates-both spherical and star-shapedas well as in the common bean star-shaped extrudates. Specifically, in both brown pea spherical and star-shaped products, a reduction in verbascose of approximately $4 \%$ and $3.2 \%$, was observed, respectively. Instead, an increase in both stachyose (by 15 and $17 \%$ ) and raffinose (by 13 and 9.7\%) for spherical and star-shaped products, were found, respectively. Although common bean star-shaped extrudates showed the same behavior as brown pea products, raffinose increased more $(16 \%)$ than stachyose $(5.5 \%)$. However, Borejszo and Khan [62] reported a decrease in raffinose and stachyose content in pinto bean flour extruded at $163{ }^{\circ} \mathrm{C}$, whereas the content of all sugars analyzed in an extruded product containing pea increased with the extrusion process [59]. Overall, and with more evidence for raffinose, we observed a higher reduction of oligosaccharides in the spherical products, obtained with a die which induced higher pressure and heat generation than the starshaped one.

\subsection{Sensory Evaluation of the Extruded Products}

The ranking test results showed that both the flour and die used had a significant influence $(p<0.05)$ on the liking of the extruded product sensory attributes (appearance, texture, taste, and aftertaste) (Table 8). Extrudates obtained from red lentil (particularly the star-shaped) were the least liked for all sensory attributes, with the worst rank sum for "texture". This result was due to their hard structure (too hard to be analyzed instrumentally with the texture analyzer), being difficult to chew, and their bland taste and aftertaste. However, red lentil spherical extrudates were liked for "appearance" and "aftertaste", similarly to spherical and star-shaped extrudates from faba bean and brown pea, as well as the star-shaped common bean. Altaf et al. [5], studying chickpea-rice-extruded snacks, reported that higher values of $\mathrm{BD}$ and hardness can make the product undesirable for the consumer. In another study, $100 \%$ lentil extrudates were less accepted than extrudates from blends of red lentil and corn [63]. On the other hand, common bean extrudates, particularly the spherical ones, were most liked for all the attributes considered, being properly puffed with a crunchy structure, pleasant taste and aftertaste.

Table 8. Characterization of extruded products (spheres and stars) by sensory attribute liking.

\begin{tabular}{clcccc}
\hline $\begin{array}{c}\text { Die } \\
\text { Configuration }\end{array}$ & \multicolumn{1}{c}{ Legume } & Appearance & Texture & Taste & Aftertaste \\
& Red lentil & $127^{\mathrm{bc} *}$ & $178^{\mathrm{b}}$ & $167^{\mathrm{a}}$ & $149^{\mathrm{ab}}$ \\
\multirow{3}{*}{ Spherical } & Faba bean & $106^{\mathrm{cd}}$ & $98^{\mathrm{cd}}$ & $124^{\mathrm{b}}$ & $121^{\mathrm{bc}}$ \\
& Brown pea & $107^{\mathrm{cd}}$ & $105^{\mathrm{cd}}$ & $101^{\mathrm{bc}}$ & $113^{\mathrm{bc}}$ \\
& Common bean & $76^{\mathrm{d}}$ & $75^{\mathrm{d}}$ & $75^{\mathrm{c}}$ & $103^{\mathrm{c}}$ \\
\hline \multirow{5}{*}{ Star-shaped } & Red lentil & $199^{\mathrm{a}}$ & $215^{\mathrm{a}}$ & $199^{\mathrm{a}}$ & $183^{\mathrm{a}}$ \\
& Faba bean & $160^{\mathrm{b}}$ & $119^{\mathrm{c}}$ & $126^{\mathrm{b}}$ & $121^{\mathrm{bc}}$ \\
& Brown pea & $132^{\mathrm{bc}}$ & $123^{\mathrm{c}}$ & $116^{\mathrm{b}}$ & $115^{\mathrm{bc}}$ \\
& Common bean & $101^{\mathrm{cd}}$ & $95^{\mathrm{cd}}$ & $100^{\mathrm{bc}}$ & $102^{\mathrm{c}}$ \\
\hline
\end{tabular}

* Sums of rank by 28 semi-trained panelists (the smaller the sum, the better the sensory attribute liking). Different letters in the columns indicate significant differences among the sums of rank for each product (different limit at $5 \%$ of $35.93, z=1.96)$, at $p<0.05$.

Overall, the spherical extrudates were more appreciated than the star-shaped ones. Shape was an intrinsic factor, able to influence the consumer perception and acceptability of the food products. It could even influence taste perception [19,64]. However, spherical and star-shaped extrudates did not show a significant difference in taste and aftertaste, probably because the difference in textural features, i.e., appearance and structure, prevailed. 


\section{Conclusions}

The results obtained represent a step forward in the attempt to understand the effect of die configuration during the extrusion of legumes. Most of the dies used in the industry have a circular cross section, which are therefore are commonly used in research investigations, whereas a star-shaped die had not been studied on legumes.

The configuration of the die significantly influenced the physico-chemical properties and sensory features of the legume-based extruded breakfast snacks. In particular, the use of the star-shaped die, with a larger cross-section, resulted in products with a lower ER and higher $\mathrm{BD}$ than the spherical extrudates, probably because of lower friction during extrusion. Furthermore, a lower extrusion pressure also induced a lower degree of starch gelatinization in the star-shaped extrudates, compared with the spherical ones, except for the red lentil-based products. The effect of the die on WAI was found insignificant, whereas WSI was higher in the spherical, rather than in the star-shaped extrudates, due to the increase of heat generation induced by elevated friction and pressure flowing through the circular die.

Spherical extrudates were characterized by higher crispiness, and lower hardness and crunchiness than the star-shaped extrudates. The brown pea spherical products were the crispiest. Moreover, the spherical products were characterized by higher $L^{*}$ and lower $a^{*}$ values (the latter with the exception of red lentil) and were more appreciated by panelists than the star-shaped extrudates. Regarding the anti-nutritional compounds, the oligosaccharides showed non univocal variations by changing the die, whereas phytates did not vary at all.

Considering that the type of legume also showed a significant influence on the qualitative and nutritional features of the extrudates-presumably related to the fiber content of the flour - the increased knowledge on the effect of the die configuration could be useful for maximizing the expansion of legume-based raw materials, in order to meet consumer expectations for healthy food products with pleasant sensory properties.

Author Contributions: Conceptualization, M.C., A.P. and C.S.; methodology, M.S., R.G., T.K. and E.S.; formal analysis, M.C.; investigation, M.C., M.S., R.G. and T.K.; data curation, M.C. and C.S.; writing—original draft preparation, M.C.; writing—review and editing, A.P., M.S., R.G., T.K., E.S. and C.S.; visualization, A.P.; supervision, A.P. All authors have read and agreed to the published version of the manuscript.

Funding: Michela Costantini acknowledges the Italian Ministry of University and Research (MIUR) and the University of Bari Aldo Moro (D.R. n. 76, 11 January 2019) for the Ph.D. grant "CUP: H94F18000200006", co-funded by European Union-FSE-FESR, PON Ricerca e Innovazione 20142020.

Institutional Review Board Statement: Not applicable.

Informed Consent Statement: Not applicable.

Data Availability Statement: The data presented in this study are available upon request from the corresponding author.

Acknowledgments: The authors are grateful to Sintija Vetra and Lolita Tomsone (Department of Food Technology, Latvia University of Life Sciences and Technologies, Jelgava, Latvia) for a valuable aid in the sensory evaluation of extruded products and for skillful technical aid in the laboratory, respectively.

Conflicts of Interest: The authors declare no conflict of interest.

\section{References}

1. Arribas, C.; Cabellos, B.; Sánchez, C.; Cuadrado, C.; Guillamón, E.; Pedrosa, M.M. The impact of extrusion on the nutritional composition, dietary fiber and in vitro digestibility of gluten-free snacks based on rice, pea and carob flour blends. Food Funct. 2017, 8, 3654-3663. [CrossRef]

2. Asif, M.; Rooney, L.W.; Ali, R.; Riaz, M.N. Application and opportunities of pulses in food system: A review. Crit. Rev. Food Sci. Nutr. 2013, 53, 1168-1179. [CrossRef] 
3. Rebello, C.J.; Greenway, F.L.; Finley, J.W. A review of the nutritional value of legumes and their effects on obesity and its related co-morbidities. Obes. Rev. 2014, 15, 392-407. [CrossRef]

4. Ganjyal, G.M. Extrusion Cooking: Cereal Grains Processing, 2nd ed.; Elsevier: Amsterdam, The Netherlands, 2020 ; p. 564.

5. Altaf, U.; Hussain, S.Z.; Qadri, T.; Ishrat, S.A.; Kanojia, V. Optimization of extrusion process for development of nutritious snacks using rice and chickpea flour. J. Sci. Ind. Res. 2020, 79, 430-436.

6. Strauta, L.; Muižniece-Brasava, S.; Gedrovica, I. Physical and chemical properties of extruded pea product. Agron. Res. 2016, 14, 1467-1474.

7. Pasqualone, A.; Costantini, M.; Coldea, T.E.; Summo, C. Use of legumes in extrusion cooking: A review. Foods 2020, 9, 958. [CrossRef] [PubMed]

8. Geetha, R.; Mishra, H.N.; Srivastav, P.P. Twin screw extrusion of kodo millet-chickpea blend: Process parameter optimization, physico-chemical and functional properties. J. Food Sci. Technol. 2014, 51, 3144-3153. [CrossRef]

9. Liene, S.; Sandra, M.B. The characteristics of extruded faba beans (Vicia faba L.). Rural Sustain. Res. 2016, 36, 42-48. [CrossRef]

10. Fenta, T.; Kumar, Y. Evaluation of processing conditions for lentil and corn blend extrudate. In Advances of Science and Technology, 6th ed.; Zimale, F., Enku Nigussie, T., Fanta, S., Eds.; Springer: New York, NY, USA, 2019; Volume 6, pp. 65-82. [CrossRef]

11. Rathod, R.P.; Annapure, U.S. Antioxidant activity and polyphenolic compound stability of lentil-orange peel powder blend in an extrusion process. J. Food Sci. Technol. 2017, 54, 954-963. [CrossRef] [PubMed]

12. Félix-Medina, J.V.; Montes-Ávila, J.; Reyes-Moreno, C.; Perales-Sánchez, J.X.K.; Gómez-Favela, M.A.; Aguilar-Palazuelos, E.; Gutiérrez-Dorado, R. Second-generation snacks with high nutritional and antioxidant value produced by an optimized extrusion process from corn/common bean flours mixtures. LWT Food Sci. Technol. 2020, 124, 109172. [CrossRef]

13. Guillermic, R.M.; Aksoy, E.C.; Aritan, S.E.R.D.A.R.; Erkinbaev, C.; Paliwal, J.; Koksel, F. X-Ray microtomography imaging of red lentil puffed snacks: Processing conditions, microstructure and texture. Food Res. Int. 2021, 140, 109996. [CrossRef] [PubMed]

14. Bekele, E.K.; Nosworthy, M.G.; Henry, C.J.; Shand, P.J.; Tyler, R.T. Oxidative stability of direct-expanded chickpea-sorghum snacks. Food Sci. Nutr. 2020, 8, 4340-4351. [CrossRef]

15. Pasqualone, A.; Costantini, M.; Labarbuta, R.; Summo, C. Production of extruded-cooked lentil flours at industrial level: Effect of processing conditions on starch gelatinization, dough rheological properties and techno-functional parameters. LWT-Food Sci. Technol. 2021, 147, 111580. [CrossRef]

16. Liu, S.Q.; Bogicevic, V.; Mattila, A.S. Circular vs. angular servicescape: "Shaping" customer response to a fast service encounter pace. J. Bus. Res. 2018, 89, 47-56. [CrossRef]

17. Li, S.; Zeng, Y.; Zhou, S. The congruence effect of food shape and name typeface on consumers' food preferences. Food Qual. Prefer. 2020, 86, 104017. [CrossRef]

18. Cafieri, S.; Chillo, S.; Mastromatteo, M.; Suriano, N.; Del Nobile, M.A. A mathematical model to predict the effect of shape on pasta hydration kinetic during cooking and overcooking. J. Cereal Sci. 2008, 48, 857-862. [CrossRef]

19. Wang, Q.J.; Carvalho, F.R.; Persoone, D.; Spence, C. Assessing the effect of shape on the evaluation of expected and actual chocolate flavour. Flavour 2017, 6, 1-6. [CrossRef]

20. Koksel, F.; Masatcioglu, M.T. Physical properties of puffed yellow pea snacks produced by nitrogen gas assisted extrusion cooking. LWT Food Sci. Technol. 2018, 93, 592-598. [CrossRef]

21. Janve, M.; Singhal, R.S. Fortification of puffed rice extrudates and rice noodles with different calcium salts: Physico-chemical properties and calcium bioaccessibility. LWT Food Sci. Technol. 2018, 97, 67-75. [CrossRef]

22. Liu, Y.; Chen, J.; Luo, S.; Li, C.; Ye, J.; Liu, C.; Gilbert, R.G. Physico-chemical and structural properties of pregelatinized starch prepared by improved extrusion cooking technology. Carbohydr. Polym. 2017, 175, 265-272. [CrossRef]

23. Smith, J.; Hardacre, A. Development of an extruded snack product from the legume Vicia faba minor. Procedia Food Sci. 2011, 1, 1573-1580. [CrossRef]

24. Luo, S.; Chan, E.; Masatcioglu, M.T.; Erkinbaev, C.; Paliwal, J.; Koksel, F. Effects of extrusion conditions and nitrogen injection on physical, mechanical, and microstructural properties of red lentil puffed snacks. Food Bioprod. Process. 2020, 121, $143-153$. [CrossRef]

25. Oliveira, L.C.; Schmiele, M.; Steel, C.J. Development of whole grain wheat flour extruded cereal and process impacts on color, expansion, and dry and bowl-life texture. LWT Food Sci. Technol. 2017, 75, 261-270. [CrossRef]

26. Summo, C.; De Angelis, D.; Ricciardi, L.; Caponio, F.; Lotti, C.; Pavan, S.; Pasqualone, A. Nutritional, physico-chemical and functional characterization of a global chickpea collection. J. Food Compost. Anal. 2019, 84, 103306. [CrossRef]

27. De Angelis, D.; Pasqualone, A.; Allegretta, I.; Porfido, C.; Terzano, R.; Squeo, G.; Summo, C. Antinutritional factors, mineral composition and functional properties of dry fractionated flours as influenced by the type of pulse. Heliyon 2021, 7, e06177. [CrossRef]

28. EN ISO. Sensory Analysis Methodology Ranking, 2006; 8587:2006; EN ISO: Geneva, Switzerland, 2006.

29. Popova, A.; Mihaylova, D. Antinutrients in plant-based foods: A review. Open Biotechnol. J. 2019, 13, 68-76. [CrossRef]

30. Samtiya, M.; Aluko, R.E.; Dhewa, T. Plant food anti-nutritional factors and their reduction strategies: An overview. Food Product. Process. Nutr. 2020, 2, 1-14. [CrossRef]

31. Ojo, M.A. Phytic acid in legumes: A review of nutritional importance and hydrothermal processing effect on underutilised species. Food Res. 2020, 5, 22-28. [CrossRef] 
32. Liu, Y.; Ragaee, S.; Marcone, M.F.; Abdel-Aal, E.S.M. Effect of different cooking methods and heating solutions on nutritionallyimportant starch fractions and flatus oligosaccharides in selected pulses. Cereal Chem. 2020, 97, 1216-1226. [CrossRef]

33. Zhang, Y.Y.; Stockmann, R.; Ng, K.; Ajlouni, S. Revisiting phytate-element interactions: Implications for iron, zinc and calcium bioavailability, with emphasis on legumes. Crit. Rev. Food Sci. Nutr. 2020, 60, 1-17. [CrossRef]

34. Kannan, U.; Sharma, R.; Gangola, M.P.; Chibbar, R.N. Improving grain quality in pulses: Strategies to reduce raffinose family oligosaccharides in seeds. Ekin J. Crop Breed. Genetic. 2018, 4, 70-88.

35. Vidal-Valverde, C.; Frias, J.; Hernández, A.; Martín-Alvarez, P.J.; Sierra, I.; Rodríguez, C.; Blazquez, I.; Vicente, G. Assessment of nutritional compounds and antinutritional factors in pea (Pisum sativum) seeds. J. Sci. Food Agric. 2003, 83, 298-306. [CrossRef]

36. Tahir, M.; Vandenberg, A.; Chibbar, R.N. Influence of environment on seed soluble carbohydrates in selected lentil cultivars. J. Food Compost. Anal. 2011, 24, 596-602. [CrossRef]

37. Abbas, Y.; Ahmad, A. Impact of processing on nutritional and anti-nutritional factors of legumes: A review. Annals. Food Sci. Technol. 2018, 19, 99-215.

38. Mohamed, S. Factors affecting extrusion characteristics of expanded starch-based products. J. Food Process. Preserv. 1990, 14, 437-452. [CrossRef]

39. Adekola, K.A. Engineering review food extrusion technology and its applications. J. Food Eng. 2016, 6, 149-168. [CrossRef]

40. Altan, A.; McCarthy, K.L.; Maskan, M. Evaluation of snack foods from barley-tomato pomace blends by extrusion processing. J. Food Eng. 2008, 84, 231-242. [CrossRef]

41. Pérez-Navarrete, C.; Gonzalez, R.; Chel-Guerrero, L.; Betancur-Ancona, D. Effect of extrusion on nutritional quality of maize and Lima bean flour blends. J. Sci. Food Agric. 2006, 86, 2477-2484. [CrossRef]

42. Liu, Y.; Hsieh, F.; Heymann, H.; Huff, H.E. Effect of process conditions on the physical and sensory properties of extruded oat-corn puff. J. Food Sci. 2000, 65, 1253-1259. [CrossRef]

43. Shirazi, S.L.; Koocheki, A.; Milani, E.; Mohebbi, M. Production of high fiber ready-to-eat expanded snack from barley flour and carrot pomace using extrusion cooking technology. J. Food Sci. Technol. 2020, 57, 1-13.

44. Lue, S.; Hsieh, F.; Huff, H.E. Extrusion cooking of corn meal and sugar beet fiber: Effects on expansion properties, starch gelatinization, and dietary fiber content. Cereal Chem. 1991, 68, 227-234.

45. Tas, A.A.; Shah, A.U. The replacement of cereals by legumes in extruded snack foods: Science, technology and challenges. Trends Food Sci. Technol. 2021, 116, 701-711. [CrossRef]

46. Kallu, S.; Kowalski, R.J.; Ganjyal, G.M. Impacts of cellulose fiber particle size and starch type on expansion during extrusion processing. J. Food Sci. 2017, 82, 1647-1656. [CrossRef]

47. Ding, Q.; Ainsworth, P.; Tucker, G.; Marson, H. The effect of extrusion conditions on the physico-chemical properties and sensory characteristics of rice-based expanded snacks. J. Food Eng. 2005, 66, 283-289. [CrossRef]

48. Hashimoto, J.M.; Grossmann, M.V.E. Effects of extrusion conditions on quality of cassava bran/cassava starch extrudates. Int. J. Food Sci. Technol. 2003, 38, 511-517. [CrossRef]

49. Shirani, G.; Ganesharanee, R. Extruded products with Fenugreek (Trigonella foenum-graecum) chickpea and rice: Physical properties, sensory acceptability and glycaemic index. J. Food Eng. 2009, 90, 44-52. [CrossRef]

50. Philipp, C.; Buckow, R.; Silcock, P.; Oey, I. Instrumental and sensory properties of pea protein-fortified extruded rice snacks. Food Res. Int 2017, 102, 658-665. [CrossRef] [PubMed]

51. Oliveira, L.C.; Alencar, N.M.; Steel, C.J. Improvement of sensorial and technological characteristics of extruded breakfast cereals enriched with whole grain wheat flour and jabuticaba (Myrciaria cauliflora) peel. LWT Food Sci. Technol. 2018, 90, 207-214. [CrossRef]

52. Brennan, M.A.; Derbyshire, E.; Tiwari, B.K.; Brennan, C.S. Ready-to-eat snack products: The role of extrusion technology in developing consumer acceptable and nutritious snacks. Int. J. Food Sci. Technol. 2013, 48, 893-902. [CrossRef]

53. Luyten, H.; Plijter, J.J.; Vliet, T.V. Crispy/crunchy crusts of cellular solid foods: A literature review with discussion. J. Texture Stud. 2004, 35, 445-492. [CrossRef]

54. Tunick, M.H.; Onwulata, C.I.; Thomas, A.E.; Phillips, J.G.; Mukhopadhyay, S.; Sheen, S.; Liu, C.K.; Latona, N.; Pimentel, M.R.; Cooke, P.H. Critical evaluation of crispy and crunchy textures: A review. Int. J. Food Prop. 2013, 16, 949-963. [CrossRef]

55. Solomon, W.K. Hydration kinetics of direct expanded tef flour breakfast cereals in water and milk. Food Sci. Nutr. 2014, 2, 39-45. [CrossRef]

56. Chan, E.; Masatcioglu, T.M.; Koksel, F. Effects of different blowing agents on physical properties of extruded puffed snacks made from yellow pea and red lentil flours. J. Food Process Eng. 2019, 42, e12989. [CrossRef]

57. Ilo, S.; Berghofer, E. Kinetics of colour changes during extrusion cooking of maize grits. J. Food Eng. 1999, 39, 73-80. [CrossRef]

58. Andersson, Y.; Hedlund, B. Extruded wheat flour: Correlation between processing and product quality parameters. Food Qual. Prefer. 1990, 2, 201-216. [CrossRef]

59. Arribas, C.; Cabellos, B.; Cuadrado, C.; Guillamón, E.; Pedrosa, M.M. The effect of extrusion on the bioactive compounds and antioxidant capacity of novel gluten-free expanded products based on carob fruit, pea and rice blends. Innov. Food Sci. Emerg. Technol. 2019, 52, 100-107. [CrossRef]

60. Ciudad-Mulero, M.; Fernández-Ruiz, V.; Cuadrado, C.; Arribas, C.; Pedrosa, M.M.; Berrios, J.D.J.; Pan, J.; Morales, P. Novel glutenfree formulations from lentil flours and nutritional yeast: Evaluation of extrusion effect on phytochemicals and non-nutritional factors. Food Chem. 2020, 315, 126175. [CrossRef] 
61. Morales, P.; Berrios, J.D.J.; Varela, A.; Burbano, C.; Cuadrado, C.; Muzquiz, M.; Pedrosa, M.M. Novel fiber-rich lentil flours as snack-type functional foods: An extrusion cooking effect on bioactive compounds. Food Funct. 2015, 6, 3135-3143. [CrossRef] [PubMed]

62. Borejszo, Z.B.; Khan, K.H. Reduction of flatulence-causing sugars by high temperature extrusion of pinto bean high starch fractions. J. Food Sci. 1992, 57, 771-777. [CrossRef]

63. Hardacre, A.K.; Clark, S.M.; Riviere, S.; Monro, J.A.; Hawkins, A.J. Some textural, sensory and nutritional properties of expanded snack food wafers made from corn, lentil and other ingredients. J. Texture Stud. 2006, 37, 94-111. [CrossRef]

64. Velasco, C.; Woods, A.T.; Deroy, O.; Spence, C. Hedonic mediation of the crossmodal correspondence between taste and shape. Food Qual. Prefer. 2015, 41, 151-158. [CrossRef] 